\title{
Refinement of Methodology for Better Estimation of Pregnancy Diagnosis in Macaca fascicularis by Deep Computational Analysis of The Thermal Images
}

\author{
(PENYEMPURNAAN METODOLOGI UNTUK DIAGNOSIS KEBUNTINGAN MONYET \\ EKOR PANJANG MELALUIANALISIS KOMPUTASIONAL CITRA TERMAL)
}

\author{
Huda Shalahudin Darusman ${ }^{1,2^{*}}$, Sony Hartono Wijaya ${ }^{3}$, \\ Ahmad Kamal Nasution ${ }^{3}$, Entang Iskandar ${ }^{2}$, Dondin Sajuthi ${ }^{2,4}$ \\ ${ }^{1}$ Department of Anatomy, Physiology and Pharmacology, \\ Faculty of Veterinary Medicine, \\ Bogor Agricultural University (IPB University) \\ Jln Agathis, Kampus IPB Dramaga, \\ Bogor, West Java, Indonesia 16680 \\ ${ }^{2}$ Primate Research Center, \\ Institute of Research and Community Service, \\ Bogor Agricultural University (IPB University), \\ ${ }^{3}$ Department of Computer Science, \\ Faculty of Mathematics and Natural Sciences (FMIPA), IPB University \\ ${ }^{4}$ Department of Clinic, Reproductive and Pathology, \\ Faculty of Veterinary Medicine, IPB University, \\ "Email: hudada@apps.ipb.ac.id
}

\begin{abstract}
Abstrak
Pemanfaatan citra termal telah terdokumentasi sebagai metode yang memberikan manfaat bagi pemeriksaan kesehatan satwa liar dengan penekanan pada pemanfaatannya sebagai metode non-invasif. Pemanfaatan metode pemeriksaan kesehatan dengan cara non-invasif ini merupakan salah satu keunggulan dari sudut pandang kesejahteraan hewan tersebut. Studi ini menitikberatkan pada pemanfaatan citra termal untuk pemeriksaan fungsi faal tubuh terutama untuk estimasi status reproduksi pada satwa primata monyet ekor panjang (Macaca fascicularis) di Pusat Studi Satwa Primata Institut Pertanian Bogor. Subyek uji adalah monyet ekor panjang betina yang telah didiagnosis bunting pada usia kebuntingan ke-80, 120 dan 130 hari. Pengambilan citra termal menggunakan kamera FLIR ONE pada hewan uji yang tersedasi pada posisi pengambilan citra dorso-ventral. Luaran yang dihasilkan adalah temperature tubuh yang selanjutnya menghasilkan data regresi linear sebagai estimasi suhu yang terukur di kamera termal terhadap usia kebuntingan, yang menunjukkan adanya korelasi positif antara pertambahan suhu dengan usia kebuntingan Selain luaran diatas, analisis komputasional deep learning dengan teknik convolutional neural network diaplikasikan pada citra termal yang dihasilkan untuk melengkapi dan mendukung akurasi diagnosis kebuntingan tersebut. Estimasi kebuntingan berbasis suhu yang didukung dengan analisis komputasional diatas meningkatkan akurasi dalam mengestimasikan usia kebuntingan yang akurat dan presisi.
\end{abstract}

Kata-kata kunci: reproduksi; teknik non-vasif;suhu; deep-learning

\begin{abstract}
The current use of thermal imaging has been documented in wild animals due to the benefit for having real-time results with less or almost no restrain or invasive methods required - and this is significant for better well-being. This paper will explore the thermal imaging studies as a part of employing non-invasive methods in evaluating physiological function, in particular with refinement of the methods, followed by further computational analysis of the images to ensure the validity of the methods as predictive tools for pregnancy diagnosis. We conducted refinements in thermal imaging methods and computational analysis
\end{abstract}


of deep learning for pregnancy diagnosis of cynomolgus monkeys (Macaca fascicularis) at breeding facility of The Primate Research Center, LPPM IPB University. Subjects were already identified by ultrasound as pregnant in 80, 120 and 130 days. Thermal images along with the temperature data were obtained from FLIR ONE camera in sedated animals with dorso-ventral recumbence. The temperature data were analyzed with linear regression to correlate the skin temperature and the days of pregnancy to make a prediction of pregnancy days based on temperature data. There is a positive correlation of the temperature to the pregnancy days with a function of temperature to days. Further computational analysis of the thermal image, the results showed that the refined methods and the computational analysis brought better interpretation to evaluate health and reproductive status, in particular with the pregnancy diagnosis.

Keywords: reproductive; non-invasive; thermal; deep-learning

\section{INTRODUCTION}

Alternatives methods to animal in biomedical research are advancing through the awareness to use all non-animal methods, such as optimizing human or animal cells (in vitro) and advanced computational-models (in silico models) (Doke and Dhawale, 2015). However, animal experimentation, with strictly follows the ethical consideration of the 3Rs (Replacement, Reduction and Refinement) concept, are still regarded as necessary when higher biological systems and interaction are required to describe the physiological impact (Bayne et al., 2010; Hubrecht and Carter, 2019; Ranganatha and Kuppast, 2012).

The non-human primates (NHP) are regarded essential in biomedical research with many discoveries and translational studies have derived from the NHP model to explain better pathophysiology of human's disease or other phenomenon (Capitanio and Emborg, 2008). Especially in the field of comparative immunology, reproductive and neurology, NHP models provide better understanding in the related field mentioned above (Capitanio and Emborg, 2008; Carlson et al., 2004; Heuer et al., 2012). The utility of the NHP as animal models are well-explained due to their closest taxonomically, anatomically, morphologically, physiologically with human being (Tardiff et al., 2013). Therefore, the use of NHP remained essential in research and given the species proximity to human also, the use of NHP in biomedical research should only limited to research with no alternative to non-primate species (Hau and Schapiro, 2004, Tardiff et al., 2013).

Growing needs to reduce the NHP and or refinement of their utilization in biomedical research are relevant with the main concern of primates' wellbeing, either in experimental design, or the husbandry methods (Tardiff et al., 2013). The assurance to quality of living of the
NHP will ensure the welfare of the animals which prevent the animal from suffering and securing the quality of the research itself from bias that caused by stress-related entities (Lyons et al., 2000). Promoting non-invasive methods in research and routine husbandry procedure are one of the best practices (NC3Rs 2018). Providing non-invasive measurements to measure physiological values to conventional clinical examination that require chemical restrains, are also considered as refinement (Dezecache et al., 2017; Hau and Schapiro, 2004). The thermal imaging may be one of the non-invasive criteria which provide a real-time measurement of the basic physiological value of body temperature thus useful to estimate the health status (Cilulko and Janiszewski, 2013; Christiansen et al., 2014). The importance of the thermal imaging becomes greater for wildlife animal use and/or certain animals that in necessity to be sedated in health examination (Dezecache et al., 2017). Thermal camera had been used for basic examination to body temperature (Christiansen et al. 2014), and with better algorithm and computerized interpretation to the thermal images, we may potentially gain more benefit. Bowers et al. (2009) applied thermal imaging to identify pregnancy status in the late-gestation mares by observing the surface temperature differences between pregnant and non-pregnant mares. In this case, late-gestation mares had higher flank temperatures than non-pregnant mares. Moreover, Krueger et al. (2019) also applied thermographic imaging for thermal pregnancy diagnosis in pregnant Babirusa (Babyrousa babyrussa) by investigating thermographic changes. With the advancement of technology in computational learning, we may gain more benefit to increase the accuracy of thermal infrared imaging results as the diagnostic tools for estimation of pregnancy period.

In this paper we aimed on refining thermal imaging methods to support the diagnosis for 
reproductive health in particular with pregnancy diagnosis period (days). Furthermore, the computational analysis of deep learning was employed to confirm the validity of the thermal images as a predictive tool to estimate the pregnancy days. Deep learning is one area of machine learning, a subset of machine learning in artificial intelligence (AI) that utilizes artificial neural networks to overcome problems with large datasets. Deep learning techniques provide a very powerful architecture for Supervised Learning. In deep learning, Convolutional Neural Network $(\mathrm{CNN})$ is a class of deep neural network and consisted of the development of multilayer perceptron (MLP) which is widely applied to process image data and its architecture can be trained and consists of several stages. By conducting a thermal imaging with combination to image processing of $\mathrm{CNN}$, potentially, it will increase the benefit of thermal imaging that complimented with 4.0 technologies of sensors and AI.

\section{RESEARCH METHODS}

\section{Subjects}

Ten adults female cynomolgus monkeys, aged 5-10 years determined by dentistry estimation with pregnancy status, identified by ultrasound diagnosis, at the $120^{\text {th }}$ and $130^{\text {th }}$ days of pregnancies were subjected in this research.
Three females with $80^{\text {th }}$ days of pregnancy and three non-pregnant females from the Primate Center facility are also generated as control of pregnancy age (from Ultrasound - USG) and status, respectively. The subjects' identity along with pregnancy age and the body temperature (recorded from thermal imaging), are presented in Table 1.

\section{Subjects and Thermal Imaging Recording}

All subjects were selected from several steps, starting from assessing the basic identity of the animals' age, health status - both clinically as well as free from basic pathogens. Females with clinically estimated as pregnant, were clinically examined by abdominal palpation to estimate the pregnancy age and followed by ultrasound examinations to provide better pregnancy age. Procedures that related with thermal image recording were done under sedation by applying Ketamine at $1 \mathrm{mg}$ per body weight by intramuscular injection, was sufficient to provide sedation for clinical, ultrasound and thermal camera recording. The thermal image was taken perpendicular to the subjects animals with dorsoventral recumbence and the distance between the camera and the subjects is $75 \mathrm{~cm}$. The image was taken in indoors condition with room temperature of $27.4^{\circ} \mathrm{C}$. The DV recumbent is considered as the ideal position to obtain the overall position of the animal's images for computational analysis. Selected thermal images

Table 1. Identity of the female subject with pregnancy periods

\begin{tabular}{llll}
\hline No. & Tattoo identity & $\begin{array}{l}\text { Days of Pregnancies (clinical and } \\
\text { ultrasound diagnosis) }\end{array}$ & $\begin{array}{l}\text { Body temperature from } \\
\text { thermal imaging }\left({ }^{\circ} \mathrm{C}\right)\end{array}$ \\
\hline 1. & T3933 & 130 days & 39.2 \\
2. & J0307108 & 130 days & 39.7 \\
3. & T3916 & 130 days & 39.2 \\
4. & I20311 & 130 days & 39.3 \\
5. & IA3497 & 130 days & 39.2 \\
6. & T3924 & 120 days & 38.3 \\
7. & C7079 & 120 days & 37.5 \\
8. & T3863 & 120 days & 38.5 \\
9. & I21218 & 120 days & 38.1 \\
10. & T3834 & 120 days & 37.9 \\
11. & 9548 & 80 days & 37.8 \\
12. & C7089 & 80 days & 37.4 \\
13. & T3836 & 80 days & 37.4 \\
14. & I10123 & 0 days & 34.1 \\
15. & A5 & 0 days & 37.1 \\
16. & C4585 & 0 days & 35.4 \\
\hline
\end{tabular}


were further processes by various computational analyses. The pregnancy status were further determined to divide the subjects characteristics where as subjects with day 0 pregnancy became the subjects of time point 1 , and later on, the subjects with day 80, 120 dan 130 of pregnancies became the subjects of time points of 2,3 , and 4.

All procedures involving animals were carried out by with The Institution's approved standard operating procedure based on The Guide for the Care and Use of Laboratory Animals by NRC 2011. The subjects' housing conditions and test procedures were approved by the Institutional Animal Care and Use Committee (ACUC) of The Primate Research Center (PRC), Bogor Agricultural University (ACUC No. IPB PRC -19-A002). The overall procedures are described schematically by flow charts in Figure 1.

\section{Thermal Imaging Preparations}

This step consists of four stages which can be described as: image acquisition, image preprocessing, prediction and evaluation. Image acquisition was initiated by collecting thermal images from the subjects using thermal camera (FLIR ${ }^{\circledR}$, ONE Pro iOS, Wilsonville Oregon, USA) with connection to smartphone.

Data pre-processing was done by resizing the thermal image into $100 \times 100$ pixels. Furthermore, the transformation of the image into a greyscale image was done so that we obtained the data with dimensions [X, $100,100,1]$, where $\mathrm{X}$ is the number of data input lines to be trained and 100,100 is the number of pixels in each image, and 1 is the dominant grayscale kernel (Rayhan et al., 2017). The last step reshaped the data set into two dimensions [X, 10000]. This two-dimensional data will be used as input for deep-learning methods of the Convolutional Neural Network (CNN) algorithm.

Input and output of each stage consists of several arrays called feature maps. Each stage consists of three layers, namely the convolution, the layer activation function and the pooling layer (LeCun and Bengio, 1995). The architecture of the CNN can be seen in Figure 2. The resulted model was then evaluated by calculating the prediction accuracy. Accuracy is the ratio between correctly predicted samples and all samples (Han et al., 2012). The CNN provide the precision and accuracies as well as the reliability of the thermal images as predictive models.

\section{RESULTS AND DISCUSSION}

Based on Table 1, the measured body temperatures from the thermal image were generated with correlational analysis to the days of pregnancy. There is a positive correlation of temperature to days of pregnancy. By applying a linear regression, the pregnancies days are positively correlated with the temperature from thermal image, i.e. the increase of temperature indicated the more days of pregnancy with linearity $\mathrm{R}^{2}=0.79$

The preliminary results indicate the potential of thermal imaging in late-pregnancy diagnosis. Physiologically, the more progressing days of pregnancy correlate with an increase of the amount of vascularization and tissues' formation and all of these will bring consequences to potential increase of temperature (Dezecache et al., 2017). Our findings support the above physiological entity. Further computational analysis of CNN has showed that the thermal images provides more information as a prediction tools for better precision in the diagnosis of pregnancy based on thermal imaging.

Figure 4 shows some sample images used in the training and testing processes. As an input, the dimension of all images was resized

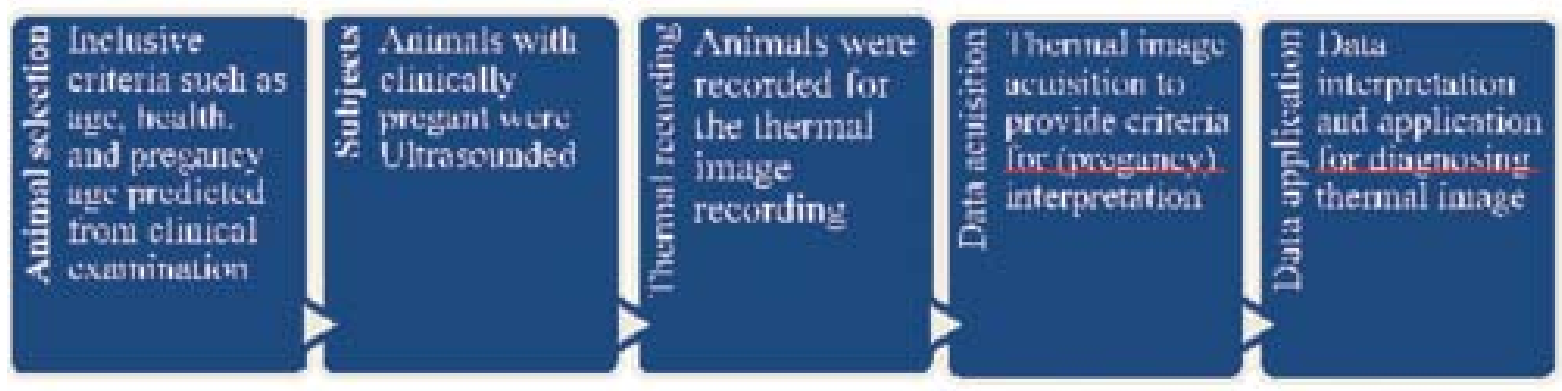

Figure 1. Flow charts of thermal imaging recording and image processing 
Table 2. Summary of the dataset of the thermal images

\begin{tabular}{lccc}
\hline Dataset & Positive class & Negative class & Total \\
\hline Training data & 53 & 38 & 91 \\
Testing data & 20 & 16 & 36 \\
\hline
\end{tabular}

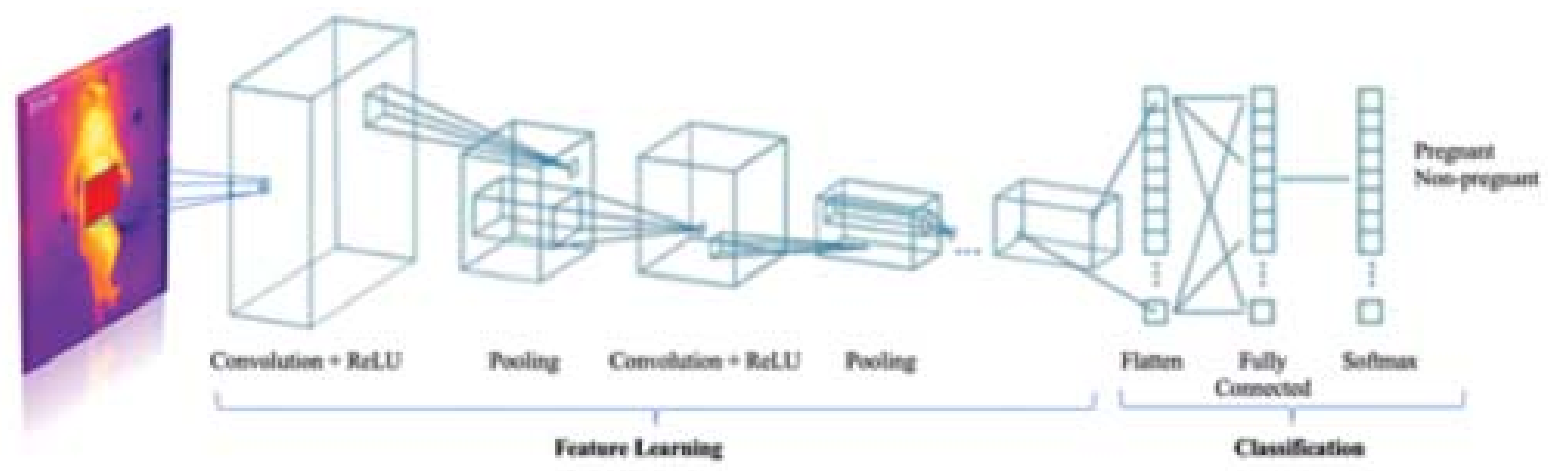

Figure 2. The architecture of Convolutional Neural Network

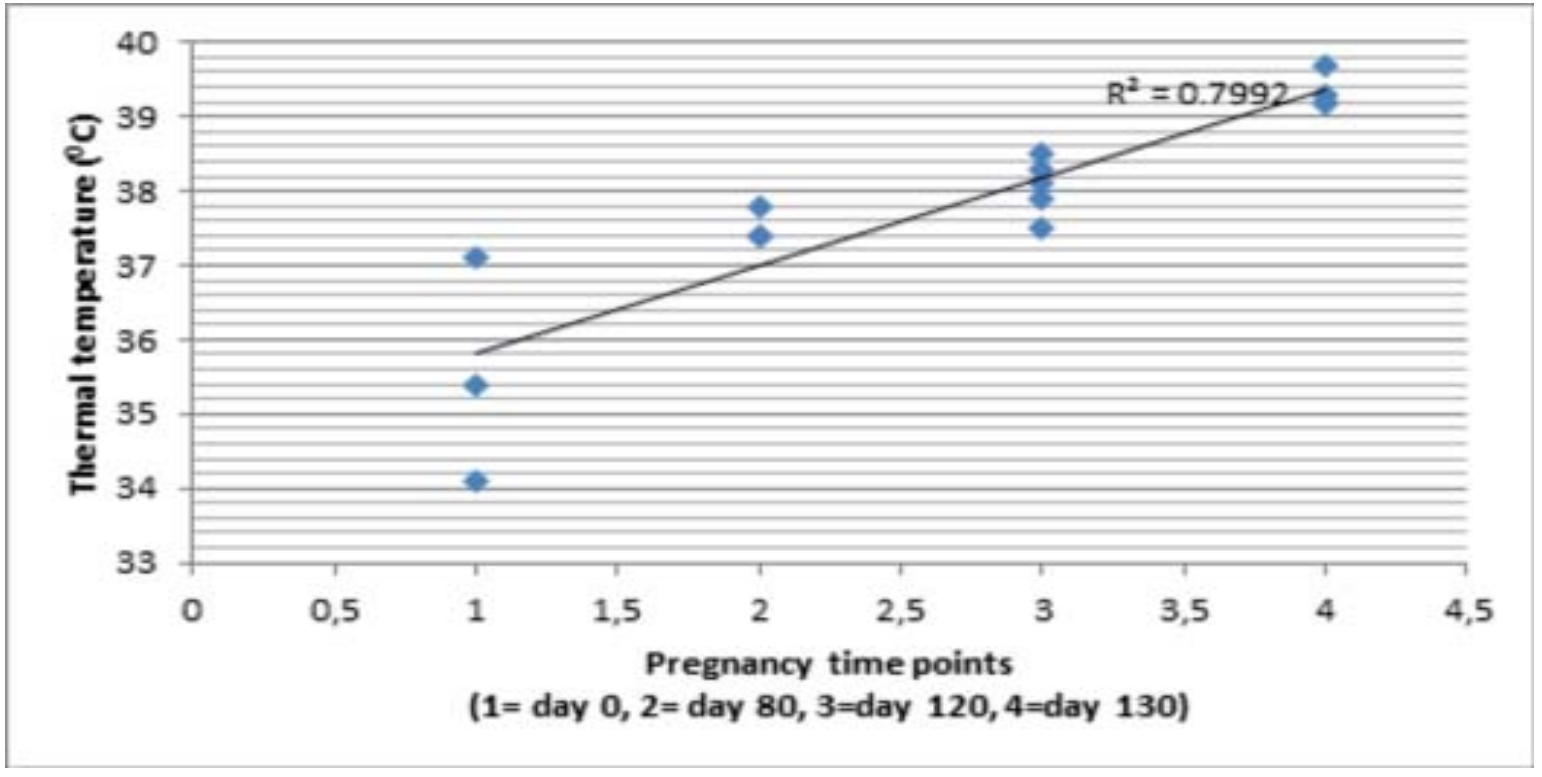

Figure 3.Linearity of days of pregnancy and thermal images. Pregnancy time points are divided into four time points. Time point 1 represent the non-pregnant female, and time points 2 , 3 and 4 represent of 80,120 and 130 days, respectively.
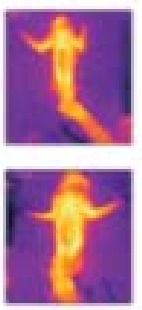
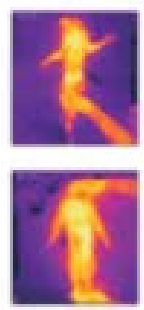
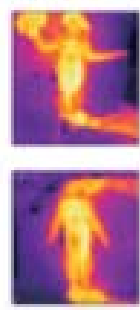
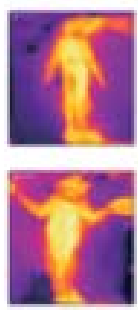
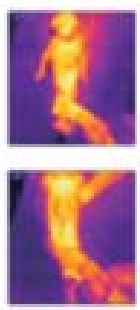

Figure 4.Examples of selected images with resizing into 100x100 pixels for image processing with CNN methods. 
into $100 x 100$ pixels. The number of data used in this study consisted of 91 and 36 images as training and testing data respectively. The primate images are grouped into two classes, namely samples from primate images experiencing pregnancy (as a positive class) and samples from primate images that are not pregnant (as a negative class). The number of positive and negative data used in testing consisted of 20 and 16 thermal images, respectively. Table 2 shows a summary of the data used in this study. In terms of prediction, we implemented the prediction model using Phyton with Keras, TensorFlow and Scikit Learn packages (Muresan and Oltean, 2018). We applied the CNN using default values for all parameters.

This study conducted training and testing data and measured by epoch values ranging from 1 to 10 and batch size $=32$. As the number of epoch increases, the number of weight is changed in the neural network and the curve goes from under-fitting to optimal curve. Whereas, the batch size represents the total number of training examples present in a single batch. The larger the epoch, the higher the prediction accuracy of training and testing data it becomes. Both accuracies slightly increase when the epoch raises from 1 to 4 and tend to be constant when epoch $\geq 8$. When $5<$ epoch $<8$, the accuracy between training and testing data work in the opposite direction, the training accuracy obtains the highest accuracy but the testing accuracy becomes extremely decrease, and vice versa. Therefore, we concluded that the best prediction model in this study was obtained when epoch 8 with $100 \%$ accuracy (obtained from training data and testing data with amount of 91 and 36 respectively, in total the results are generated from 127 data). Based on the epoch values, the prediction model is perfectly able to predict the pregnancy status of ten adult female cynomolgus monkeys based on thermal imaging.

\section{CONCLUSIONS}

The thermal imaging provided adequate support for health management and diagnosis to physiological function on a thermal basis - in this study. The pregnancy periods were sufficiently predicted by the increase of heat of the abdominal cavity and positively correlate with the days of pregnancy. Further, the image processing by CNN, measured from epoch values, provided a good prediction model to identify the pregnancy status of ten adult female cynomolgus monkeys based on thermal imaging. All of these findings were then confirming the utility of thermal imaging as a prediction of pregnancy days.

\section{SUGGESTIONS}

The resulting model has very good accuracy. Further exploration of computational analysis with a bigger data set and localization of object of interest would be beneficial to complete a better and consistent model of thermal imaging to estimate the pregnancy period by the computational analysis of CNN. Future studies in relation with correlation of the thermal and image quality with the hormonal level indicative of reproductive status will be beneficial to describe the validity of this imaging studies with physiological status of the animals.

\section{ACKNOWLEDGEMENTS}

The author is thankful for the meticulous help and assistance from the veterinarian and the staff at the Breeding Facility and Administration office of Primate Research Center of Bogor Agricultural University, Dr Suzy Tomonggo, Tita Ratnasari, Diyan Agustina and all animal caretakers. This research is funded by the Ministry of Research Technology and Higher Education (Kemenristekdikti) under the scheme of applied research (PTUPT) of AgroMaritim 4.0 (Contract number:3/E1/ KP.PTNBH/2019).

\section{REFFERENCES}

Bayne K, Morris TH, France MP. 2010. The UFAW handbook of the care and management of laboratory and other research animals. Eight edition. Amsterdam. Elsevier BV. Pp. 107-123.

Bowers S, Gandy S, Anderson B, Ryan P, Willard S. 2009. Assessment of pregnancy in the late-gestation mare using digital infrared thermography. Theriogenology 72(3): 372377. 
Carlsson HE, Schapiro SJ, Farah I, Hau J. 2004. Use of primates in research: a global overview. Am J Primatol 63: 225-237.

Capitanio JP, Emborg ME. 2008. Contribution of nonhuman primate to neuroscience research. Lancet 317: 1126-1135

Christiansen P, Steen KA, Karstoft H. 2014. Automated detection and recognition of wildlife using thermal cameras. Sensors 14(8): 13778-13793.

Cilulko J, Janiszewski P. 2013. Infrared thermal imaging in studies of wild animals. Eur $J$ Wildlife Res 59: 17-23.

Dezecache G, Wilke C, Zuberbuhler. 2017. Skin temperature and reproductive condition in wild female chimpanzee. Peer J 4116: 1-18. doi:10.7717/peerj.4116.eCollection 2017.

Doke SK, Dhawale SC. 2015. Alternatives to animal testing: A review. Saudi Pharm J 23(3): 223-229.

Hau J, Schapiro SJ. 2004. The welfare of nonhuman primates, in: The welfare of laboratory animals. Dordrecht. Kluwer. Pp. 291-314.

Han J, Kamber M, Pei J. 2012. Data mining concept and techniques ed., Waltham. Elsevier Inc. Pp. 21-27.

Heuer E, Rosen RF, Cintron A, Walker LC. 2012. Nonhuman primate models of alzheimer-like cerebral proteopathy. Curr Pharm Des 18: 1159-1169

Hubrecht RC, Carter E. 2019. The 3Rs and Humane Experimental Technique:
Implementing Change. Animals (Basel) 9(10): 754-764. doi: 10.3390/ani9100754.

Krueger F, Knauf-Witzens T, Getto S. 2019. New approach in thermal pregnancy diagnosis: Teat's heating in babirusa (Babyrousa babyrussa). Theriogenology 133: 144-148.

LeCun Y, Bengio Y. 1995. Convolutional networks for images, speech, and time series. The handbook of brain theory and neural networks. Montreal. U Montreal Ca. Pp. 199-195.

Lyons DM, Lopez JM, Yang C, Schatzberg AF. 2000. Stress-level cortisol treatment impairs inhibitory control of behavior in monkey. $J$ Neurosci 20: 7816-7821.

Mure an H, Oltean M. 2018. Fruit recognition from images using deep learning. Acta Universitatis Sapientiae, Informatica 10(1): 26-42.

Ranganatha N, Kuppast IJ. 2012. A review on alternatives to animal testing methods in drug development. Int J Pharm 4: 28-32.

Rayhan F, Ahmed S, Mahbub A, Jani MR, Shatabda S, Farid DM. 2017. Cusboost: Cluster-based under sampling with boosting for imbalanced classification. arXiv: 1712.04356. https://arxiv.org/pdf/ 1712.04356. [12 Oktober 2019].

Tardiff SZ, Coleman K, Lutz C. 2013. IACUC review of nonhuman primate research. ILAR J 54(2): 234-245. 